(heath rush). With the co-operation of the Ministry of Transport and Civil Aviation radar station at Great Dun Fell $(2,780 \mathrm{ft}$.) of the Meteorological Office, it is hoped to initiate a range of automatic recordings of meteorological data at that point, which will in future be compared with those being taken at Moor House and at Alston. Establishment of the Cairngorms Nature Reserve has made possible a partial filling of a serious gap in the snow survey of Britain, and autographic temperature-recording has now started at Loch Etchachan (3,058 ft.), where weekly readings are taken during April-October.

The present status in Britain of the hare has also been investigated, as well as the population density and feeding habits of the buzzard in sample areas throughout the country. No evidence of an extensive switch of diet by predators in directions harmful to human interests has so far been traced to the disappearance of rabbits. The measurement of longterm changes in the vegetation on grasslands, particularly where rabbit-grazing has been suddenly reduced by myxomatosis, continued, and at Bridgwater Bay measurements were made of the rate of shingle movement along the beach and its relation to the growth of the cord grass, Spartina townsendii. At Braunton Burrows the closing of blow-outs by brushwood and hessian fencing, together with the planting of Ammophila arenaria, increased the height of the coastal dune ridge by five to six feet, while the untreated central ridge was lowered by a similar amount and the inner ridge encroached landward by about $25 \mathrm{ft}$. a year. As a result of the Conservancy's continued experiments on spraying of roadside verges and hedgerows, the Ministry of Transport and Civil Aviation issued a circular on the use of selective weedkillers containing substituted phenoxyacetic acids for control of roadside vegetation to all appropriate local authorities. The Nature Conservancy also investigated during April-June 1955 complaints of killing of lambs by golden eagles in Lewis, as a result of which no amendment of the law forbidding the killing of this bird was considered necessary.

A list of scientific publications of the Conservancy is included in the report.

\section{THE NATIONAL PARKS COMMISSION, GREAT BRITAIN ANNUAL REPORT}

$\mathrm{W}$ ITHIN the limits set by its financial resources and the neglect to implement fully the administrative provisions of the National Parks and Access to the Countryside Act, the sixth annual report of the National Parks Commission, covering the year ended September 30, 1955*, gives a reasonably encouraging record of progress. The education of the public and of government departments, public corporations and local authorities has been patiently, tactfully and persistently pursued. Firm opposition has been maintained, so far as the Commission's powers permit, to proposals which threaten the purposes for which the parks were created, and although there is no immediate prospect of extending the list of areas designated as national parks the Commission is giving increasing attention to the designation of

* National Parks and Access to the Countryside Act, 1949. Sixth Report of the National Parks Commission for the year ending 30th September, 1955. Pp. iv $+60+8$ plates. (London: H.M. Stationery areas of outstanding natural beauty. Administrative arrangements for the Exmoor and Yorkshire Dales National Parks have not yet been settled, nor for the Brecon Beacons Park or the Northumberland National Park designated on September 20, 1955. At the same time, the Border National Forest Park, including Kielder Forest and the adjoining forests of Kershope in Cumberland and Newcastleton and Wauchope in Roxburghshire, was established in a joint notice issued by the Forestry Commission and the National Parks Commission.

Generally, the administration of the parks proceeded smoothly, and the Commission advocates the introduction of a system of retirement by rotation for each park planning authority, so as to secure some flexibility and continuity of membership. The Commission commends particularly the sctivity of the Peak Park Planning Board in securing public access to the Kinder and Bleaklow plateaux : the seven access agreements already approved by the Minister cover some $9,34.5$ acres. Much positive action has been taken in providing car parks, the improvement of caravan sites and the removal of undesirable advertisements ; and the Board's warden service has earned the gratitude of landowners and farmers for their work, especially for their help in freeing sheep during winter snowstorms. The Lake District Planning Board has likewise given much attention to camping and caravan sites, car parks, the planting of trees and removal of offensive advertisements, and its lease of a large house at Hassness, Buttermere, to the Ramblers' Association Services, Ltd., for use as a hotel is characterized as a milestone in the history of national parks in Britain. At the opening ceremony the Commission's chairman, Lord Strang, congratulated the Board also on being the first park planning authority to provide a new public right-of-way, and on opening the first camping and caravanning site to be available under the powers of the Act. The activities of the other park planning authorities have been on similar lines. The Snowdonia Joint Advisory Committee, for example, is giving increasing attention to publicity, and, like the Pembrokeshire National Park Committee, to the clearance of disfiguring structures from sites used during the War by the Services. The Dartmoor National Park Committee has been asked to deal informally with the denial of access, and the Committee has diligently pursued various methods of dealing with the litter problem. The progranme of the North York Moors Park Planning Comnaittee includes a scheme for the protection of the wild daffodils in the valley of the proposed Farndale Local Nature Reserve and publication of a guide book to the Reserve.

In referring to the question of a National Park in Cornwall which has recently been examined once more, the Commission expresses some doubt whether the long, narrow and discontinuous coastal stretches of Cornwall are in all respects suitable for designation as a national park, and whether their administration as such would be practicable. It proposes, therefore, to consider designating coastal areas in Cornwall, and also in Devon and Dorset, with as much of their hinterland as merits inclusion, as areas of outstanding beauty. The experience gained in this way should show whether the provisions of the Act in regard to such areas are adequate, or whether some further legislative measure of protection is required. The Commission has in the meantime already made proposals for designating the Gower Peninsula and the 
Quantocks as areas of outstanding natural beauty, and is in informal consultation with the county councils about the Surrey hills and the Lleyn. The effect of such designation is chiefly to apply to such areas the powers conferred by the Act for the preservation and enhancement of natural beauty, and projects for these purposes, approved by the Minister, qualify for Exchequer grants of 75 per cent.

Tho other area considered by the Commission during the year as a possible national park, the Broads, presents problems not encountered elsewhere. The Broads themselves are diminishing in area, and this encroachment of land on water results from a complicated natural process not yet fully understood. Neither the origin of the lagoons nor the causes of their in-filling has yet received more than superficial investigation, and the Commission considers that such a scientific survey is an essential preliminary to any decision as to whether and at what points and at what cost restoration could be undertaken with any hope of success. Arrangements for such a survey are being discussed with the Nature Conservancy and the Ministry of Housing and Local Government, and it is hoped that the task will be undertaken by the Nature Conservancy in the near future.

Disappointment is again expressed at the slow rate of progress with the 'long distance routes', and the Commission's dissatisfaction with the Minister's decision to uphold the Manchester Corporation's contention in regard to the Pennine Way and Crowden Great Brook is recorded. Little progress was made in the establishment of new rights of way for the Cornwall north and south coast sections of the South-West Peninsula coast path; but more encouraging reports are given of the Pembrokeshire coast path, the Flamborough coast route and the South Downs route; a Welsh Highland route is under consideration. The Commission has been able to increase its publicity activities and plans to make more information availablo about the national parks and the long-distance routes and, as already noted. the ever-present problem of litter receives increasing attention under the publicity campaign with the Country Code.

In regard to development questions, the Commission notes that the Service departments consult the Commission on their proposals for the acquisition of land and erection of buildings and associated works required for the defence programme when these fall within areas in which the planning authorities know the Commission is interested. To ensure that the Commission is made aware of such proposals at the earliest opportunity and to facilitate liaison, the Commission now proposes to supply the Service departments with copies of special maps showing the areas in which it is interested. The Commission's views on the reconciliation of the claims of amenity with the duties of area boards to supply electricity at the lowest possible cost are reiterated; as a result of a general discussion with the Central Electricity Authority in which the Commission stressed the value of early consultation on new projects in areas of special landscape value, it is hoped to build up local liaison and by its means reach acceptable compromises. Meanwhile, the Ministry of Fuel and Power announced on June 27 that the North-Western Electricity Board has agreed to lay underground the whole of the new supply lines as far as Rosthwaite, including the circuit of Derwentwater, but decision on the remaining sections of the Borrowdale line are awaited. The Board has also announced that there will be no additional charge to consumers for the Hartsop scheme or in any other area where the Board is placing lines underground to preserve the beauty of the existing scene. As regards the North Wales hydroelectric power proposals, the Commission, while not offering outright opposition to the Bill embodying the Ffestiniog and Rheidol schemes, has submitted a detailed memorandum directing attention to points requiring special consideration, and it insists that it is essential that its representations should reach the Parliamentary Committee in the form in which they are made. This procedure has now been agreed with the Minister.

In regard to the proposed road racing circuit in the Peak District National Park under discussion by the Derbyshire County Council, the Commission records the opinion that it cannot see how any such proposals could be consistent with the maintenance of the area as a national park. The Conference of Park Planning Authorities held in London on July 26 provided a valuable opportunity for discussion of problems and for the demonstration of community of view.

\section{THE DEVELOPMENT OF THE POLAROGRAPH}

$\mathrm{T}$

${ }^{1} \mathrm{HE}$ thirtieth anniversary of the invention of the polarograph was marked by Prof. J. Heyrovskýs recent visit to Great Britain at the invitation of the Polarographic Society, when he took the opportunity of delivering his presidential address to the Society, given in London at the Royal Institution on November 16. Prof. Heyrovský began by pointing out that 1925 was to some extent a nominal date for the invention of the polarograph. Like most inventions, it took a year or so to conceive and develop. The original design is still in use, and its performance is, in fact, superior to many of the commercial instruments which have been developed from it.

The exact reproducibility of the current-voltage curves obtained with the dropping-mercury electrode had made it worth-while to construct an automatic device (the polarograph) for the purpose of recording such curves. Therefore, in the original meaning of the word 'polarography' the use of an exactly reproducible electrode was of greater significance than the use of automatic recording. In recent years, however, there has been a tendency to neglect the importance of reproducibility and to apply the term "polarography' to the automatic recording of current-voltage curves in general. Nevertheless, Prof. Heyrovský considered it desirable to restrict the use of the word to the investigation of all aspects of the dropping. or streaming-mercury electrode. These include a number of phenomena that are studied by currenttime or potential-time curves. The current-voltage curves of solid olectrodes, which were studied many years before the introduction of the polarograph, were not reproducible and so did not constitute polarography in the strict sense of the word, even though they might be obtained by means of the polarograph. Such considerations govern the inclusion of material in the well-known bibliography which is maintained by the Polarographic Institute of the Czechoslovak Academy of Science.

With regard to the capillary, the mercury flowrate should not exceed $2 \mathrm{mgm}$. $/ \mathrm{sec}$. In concentrated solutions, failure to adhere to this condition leads to 